\title{
Respiratory syncytial virus infection-associated hospitalization in adults: a retrospective cohort study
}

Cheryl Volling ${ }^{1,2}$, Kazi Hassan ${ }^{1}$, Tony Mazzulli ${ }^{1,2,3}$, Karen Green ${ }^{1}$, Ahmed Al-Den ${ }^{1}$, Paul Hunter ${ }^{1}$, Rupi Mangat ${ }^{1}$, John $\mathrm{Ng}^{1}$ and Allison McGeer ${ }^{1,2,3^{*}}$

\begin{abstract}
Background: Once considered primarily a pediatric concern, respiratory syncytial virus (RSV) infection is gaining recognition as a cause of significant morbidity and mortality in adults. A better understanding of RSV epidemiology and disease in adults is needed to guide patient management and to assess the need for prophylaxis, vaccines, and treatments.

Methods: We conducted a retrospective cohort study of adults admitted to four hospitals in Toronto, Canada, between September 2012 and June 2013 with RSV identified by a qualitative real-time reverse-transcriptase polymerase chain reaction assay in nasopharyngeal swab or bronchoscopy specimens. Main outcomes were hospital length of stay, need for intensive care unit (ICU) or mechanical ventilation, and all-cause mortality.
\end{abstract}

Results: Eighty-six patients were identified as requiring hospitalization for RSV infection ( $56 \%$ female). Median age was 74 (range 19-102) years; 29 (34\%) were < 65 years. Eighty-three (97\%) had underlying chronic medical conditions; 27 (31\%) were immunosuppressed, and 10 (12\%) known smokers. The most common symptoms and signs were cough in 73 (85\%), shortness of breath in 68 (79\%), sputum production in 54 (63\%), weakness in 43 (50\%), fever in 41 (48\%), and wheezing in 33 (38\%). Lower respiratory tract complications occurred in 45 (52\%), cardiovascular complications occurred in 19 (22\%), and possible co-pathogens were identified in 11 (13\%). Sixty-seven (78\%) were treated with antibiotics and 31 (36\%) with anti-influenza therapy. Thirteen (15\%) required ICU care and 8 (9\%) required mechanical ventilation. Five (6\%) died during hospitalization. Need for ICU and mechanical ventilation were associated with mortality ( $P \leq 0.02$ ). Median hospital length of stay was 6 days (mean 10.8 days).

Conclusions: RSV infection is associated with the need for extended hospital stay, ICU care and mortality in adults of all ages with chronic underlying conditions. Presenting signs and symptoms are nonspecific, co-infections occur, and patients often receive antibiotics and anti-influenza therapy. There is need for ongoing research and development of RSV prophylaxis, vaccines and treatments for adults.

Keywords: Respiratory syncytial virus, Hospitalization, Adults

\footnotetext{
* Correspondence: amcgeer@mtsinai.on.ca

'Department of Microbiology, Mount Sinai Hospital, Room 210, 600

University Avenue, M5G 1X5 Toronto, ON, Canada

${ }^{2}$ Department of Medicine, University of Toronto, Toronto, Canada

Full list of author information is available at the end of the article
} 


\section{Background}

RSV is the most common cause of serious lower respiratory tract infection in infants and young children, but immunity to RSV is incomplete and infections recur throughout life [1-10]. In adults, RSV was long thought to cause primarily mild upper respiratory tract infections. Estimates of adult hospitalization, morbidity and mortality attributable to RSV have varied, likely due to a lack of routine testing for respiratory viruses in adult acute respiratory illness and the poor sensitivity of many test methods when performed [11]. Over the last several decades, however, studies have shown that RSV causes more severe infection in the elderly, and in adults with immune compromising and chronic cardiopulmonary conditions [3,4,9,12-19]. There now is growing evidence that rates of health care utilization, hospitalization, morbidity and mortality among adults with RSV infection may be similar to those observed with influenza infection [9,20-25].

More recent studies also suggest that RSV causes greater morbidity in younger and healthier adult populations than previously appreciated [4,26-28]. A prospective study of RSV infections in previously healthy working adults aged 18-60 found that $26 \%$ had LRTI symptoms and 38\% required time away from work during their illness [4]. In studies of previously healthy military recruits, $11-14 \%$ with respiratory symptoms were found to have RSV and most were unwell enough to require time away from duty $[26,27]$. Previously healthy adults have also been shown to have altered airway reactivity for weeks following RSV infection [29].

In order to better understand the burden of adult disease due to RSV, we undertook a retrospective study of hospitalization due to RSV infection in adults in four acute care hospitals in Toronto, Canada, during a winter season in which routine testing for RSV was added to all specimens submitted for respiratory virus testing.

\section{Methods}

\section{Study location and design}

A retrospective case series was conducted at four tertiary care adult teaching hospitals in the University of Toronto system: the three acute care hospitals of the University Health Network: Toronto General Hospital, Toronto Western Hospital, and the Princess Margaret Cancer Centre; and the Mount Sinai Hospital. Together these hospitals have 1208 beds for adults, providing 412,000 adult patient care days annually.

\section{Virus identification}

A single laboratory provides microbiology service for these hospitals. During the 2012-2013 winter season, qualitative real-time reverse transcriptase polymerase chain reaction (RT-PCR) testing for influenza and RSV was performed using the Simplexa Flu A/B \& RSV assay (Focus Diagnostics, Cypress, CA). Specimens from ICU patients, and all bronchoscopy specimens were also tested for respiratory viruses using the Seeplex RV15 ACE detection kit (RV15; Seegene, South Korea) panel at the Ontario Public Health Laboratory. At Mount Sinai Hospital, all patients admitted between October 15, 2012 and March 31, 2013 with either a diagnosis of a respiratory infection or symptoms including fever and cough had nasopharyngeal (NP) swabs submitted for RSV and influenza testing; at the remaining three hospitals, testing for the presence of respiratory viruses was at the discretion of attending physicians. All other laboratory testing was at the discretion of attending physicians.

\section{Study population}

The microbiology laboratory database was used to identify all patients $\geq 18$ years of age admitted to any of the four hospitals who had a specimen in which RSV was identified between September 2012 and June 2013.

Cases were excluded if RSV infection was judged to be incidental to hospital admission: that is, if patients were admitted either with a non-respiratory, non-cardiovascular diagnosis that was unrelated to RSV infection, or if their respiratory symptoms were not acute and were adequately explained by another diagnosis. Patients were also excluded if they had possible or definite healthcare associated disease: that is, if they had a negative specimen within three days of admission followed by a later positive specimen, or if they developed symptoms which led to NP swab testing more than 7 days after admission.

\section{Data collection}

Electronic and paper medical charts were reviewed and information was collected for each patient on baseline characteristics, comorbid illness, medications (including steroids, immunosuppressive medications, and recent chemotherapy), presenting symptoms and signs, treatments, and outcomes including complications, respiratory failure requiring mechanical ventilation, need for ICU, hospital length of stay and mortality.

\section{Statistical analysis}

All data entry and analysis was performed in SAS, version 9.3 for PC. Data were entered in duplicate and cleaned prior to analysis. Comparison of proportions was performed using chi-square and Fisher's exact tests, as appropriate, and comparisons of continuous variables performed using Wilcoxon rank sum tests. P-values of $\leq 0.05$ were considered significant.

The University Health Network and Mount Sinai Hospital research ethics boards granted approval of this study. 


\section{Results}

Population

From September 2012 to June 2013, ninety-five hospitalized patients with a positive test for RSV were identified. Six patients met criteria for hospital-acquired infection (positive specimens obtained a median of 20.5 days, range 12-23 days after admission) and three patients presented with RSV infections unrelated to the reason for hospitalization (1 each admitted for reactivation of tuberculosis, pulmonary embolism, and lung cancer with hemoptysis)

Thus, eighty-six adult patients were identified with RSV infection requiring hospitalization and are included in the analysis. Hospital admission associated with RSV infection was most commonly seen from December to April, during which time $>3 \%$ of all specimens submitted for testing were positive for RSV (Figure 1).

Baseline characteristics of included patients are detailed in Table 1. Their median age was 74 years (range 19-102) and $56 \%$ were female. Eighty-three (97\%) had chronic underlying medical conditions, of whom 27 (31\%) were immunosuppressed (15\% due to disease, 59\% due to therapy, and $26 \%$ due to both disease and therapy). Immunosuppressed patients tended to be younger (median age 62 years v. 81 for immunocompetent patients), although the prevalence of immunosuppression among those younger than age $65(8 / 29$ or $28 \%)$ was similar to that in older adults $65(19 / 57$ or $33 \%)$.

\section{Signs and symptoms}

The median duration from symptom onset to admission was 4 days (range $0-30$, interquartile range 2-6.75 days). The most common presenting signs and symptoms were cough, shortness of breath, sputum production, weakness, fever, and wheezing (Table 1). The most common reasons for presentation to hospital recorded in triage or

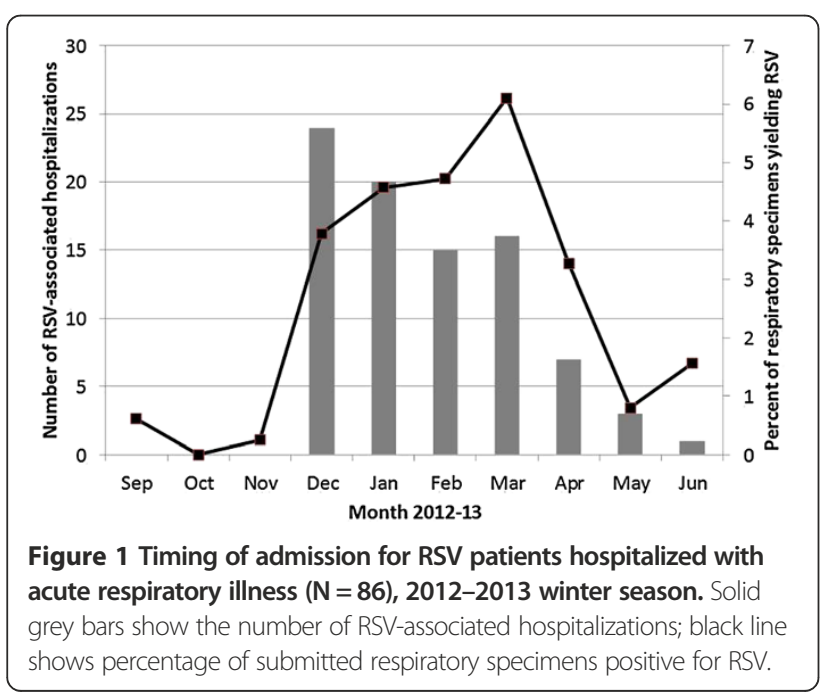

Table 1 Baseline characteristics, signs and symptoms ${ }^{1}$ of 86 patients hospitalized with RSV infection, 2012/13 winter season

\begin{tabular}{ll}
\hline Baseline characteristic & Number (\%) \\
\hline Age, median (range) & 74 years (range 19-102) \\
Female gender & $48(56 \%)$ \\
Institutionally-acquired ${ }^{2}$ & $14(16 \%)$ \\
Underlying illness (any) & $83(97 \%)$ \\
Lung disease & $31(36 \%)$ \\
Cardiac disease & $45(52 \%)$ \\
Immunosuppression ${ }^{3}$ & $27(31 \%)$ \\
Diabetes mellitus & $27(31 \%)$ \\
Known smoker & $10(12 \%)$ \\
Presenting symptoms/signs & \\
Cough & $73(85 \%)$ \\
Dyspnea & $68(79 \%)$ \\
Sputum production & $54(63 \%)$ \\
Weakness & $43(50 \%)$ \\
Fever (T > 38.0 $\left.0^{\circ} \mathrm{C}\right)$ in emergency department & $41(48 \%)$ \\
Wheezing & $33(38 \%)$ \\
Lethargy/malaise & $27(31 \%)$ \\
Runny nose or nasal congestion & $19(22 \%)$ \\
\hline
\end{tabular}

${ }^{1}$ Symptoms present in $>20 \%$ of patients are shown in table; less common symptoms included: sore throat in $16(19 \%)$, altered LOC $16(19 \%)$, chest pain $15(17 \%)$, nausea $15(17 \%)$, vomiting $14(16 \%)$, loss of appetite $14(16 \%)$, diarrhea 11 (13\%), dizziness 11 (13\%). Abdominal pain, headache, arthalgias and myalgias were reported in $<10 \%$ of patients.

${ }^{2}$ Institutions included nursing homes (8), retirement homes (3), rehabilitation or convalescent care facilities (2), and mental health hospitals (1).

${ }^{3}$ Immunosuppressed patients included those with hematologic malignancy, solid tumor on chemotherapy at time of RSV diagnosis, organ transplant, vasculitis, lupus, inflammatory bowel disease, or pulmonary fibrosis on immunosuppressive medications at time of RSV diagnosis.

ED consultation notes were shortness of breath in 55 (64\%) patients and cough in 38 (44\%) patients. The cough was described as productive in 20 (23\%) patients.

\section{Outcomes}

Lower respiratory tract complications were diagnosed in $45(52 \%)$ patients (Table 2), with 5 (6\%) diagnosed with an acute exacerbation of asthma, $11(13 \%)$ with an acute exacerbation of COPD, and 34 (40\%) with pneumonia. Twenty-six (30\%) of patients had radiographic abnormalities consistent with pneumonia. There was variability in radiographic appearance of pneumonia including unifocal infiltrates in 18 (21\%) patients, multifocal infiltrates in 8 (9\%) patients, and lobar consolidation in 11 (13\%) patients. Twenty-two cardiovascular complications were diagnosed in 19 (22\%) patients, including CHF exacerbation in 12 (14\%), new arrhythmia in 7 (8\%), stroke in 2 (2\%), and myocardial infarction in 1 (1\%).

No patients had concomitant bacteremia. Eleven (13\%) patients had potential bacterial $(n=9 ; 11 \%)$ or viral $(n=2$; 
Table 2 Complications and outcomes of 86 patients hospitalized with RSV infection, 2012/13 winter season

\begin{tabular}{|c|c|}
\hline Complication/outcome & Number (\%) \\
\hline Lower respiratory tract complications $^{1}$ & $45(52 \%)$ \\
\hline Cardiovascular complications $^{2}$ & $19(22 \%)$ \\
\hline Pneumonia ${ }^{3}$ & $34(40 \%)$ \\
\hline Confirmed radiologically & $26(30 \%)$ \\
\hline Unifocal infiltrate & $18(21 \%)$ \\
\hline Multifocal infiltrates & $8(9 \%)$ \\
\hline Lobar consolidation & $11(13 \%)$ \\
\hline Co-pathogen identified ${ }^{4}$ & $11(13 \%)$ \\
\hline Viral $^{5}$ & $2(2 \%)$ \\
\hline Bacterial $^{6}$ & $9(11 \%)$ \\
\hline Need for intensive care & $13(15 \%)$ \\
\hline Need for invasive mechanical ventilation & $8(9 \%)$ \\
\hline In hospital mortality & $5(6 \%)$ \\
\hline Median time to death (range) & 6 days ( $2-52$ days) \\
\hline Median hospital length of stay (range) & 6 days ( $1-140$ days) \\
\hline \multicolumn{2}{|c|}{$\begin{array}{l}\text { 1'Lower respiratory tract complications included exacerbation of COPD }(n=11) \\
\text { or asthma }(n=5) \text {, or pneumonia }(n=34) \text {. } \\
{ }^{2} \text { Cardiovascular complications included new arrhythmia }(n=7), C H F \\
\text { exacerbation }(N=12) \text {, myocardial infarction }(n=1) \text {, and stroke }(n=2) \text {. } \\
\text { 3Pneumonia as diagnosed by treating physicians. } \\
{ }^{4} \text { Co-ppathogen identified in nasopharyngeal swab, sputum or bronchoscopy } \\
\text { specimen culture within } 5 \text { days of admission. No patients had } \\
\text { concomitant bacteremia. } \\
\left.{ }^{5} \text { Viral co-pathogens included influenza A ( } n=1\right) \text {, and both influenza B and } \\
\text { CMV in another patient. } \\
6 \text { Bacterial co-pathogens included Haemophilus influenzae }(n=3) \text {, methicillin- } \\
\text { sensitive Staphylococcus aureus }(n=1) \text {, Streptococcus pyogenes }(n=1) \text {, Streptococcus } \\
\text { pneumoniae }(n=2) \text {, methicillin-resistant Staphylococcus aureus }(n=1) \text {, and } \\
\text { Pseudomonas aeruginosa }(n=1) \text {. }\end{array}$} \\
\hline
\end{tabular}

2\%) co-pathogens identified from NP swab, sputum or bronchoscopy specimen cultures (Table 2). Bacterial copathogens were identified in 5/34 (15\%) patients with and 4/52 (8\%) of patients without clinician- diagnosed pneumonia. Antibiotics were prescribed to $78 \%$ of patients and anti-influenza medications were prescribed to $36 \%$. Antibiotic prescription was significantly more common in those with a diagnosis of pneumonia (34/34 (100\%) v. $33 / 52(64 \%), p=<0.01)$, and somewhat more likely in patients for whom a potential co-pathogen was identified (11/11 (100\%) v. 56/75 (75\%), p = 0.06). Immunosuppressed patients were more likely to be prescribed antibiotic therapy $(26 / 27$ (96\%) v. 41/59 (70\%), p = 0.01). Ribavirin was prescribed for eight of 27 (30\%) immunosuppressed patients, and no immunocompetent patients.

ICU care was required in 15\% of patients and 9\% required invasive mechanical ventilation. In hospital mortality was $6 \%(5 / 86)$, and the causes of death were documented as respiratory failure secondary to RSV infection $(\mathrm{n}=1)$, aspiration pneumonia $(\mathrm{n}=1)$, cardiac arrest due to vertebrobasilar stroke and aspiration pneumonia $(\mathrm{n}=1)$, and multiorgan failure $(\mathrm{n}=2)$. Time from admission to death in these 5 patients was $3,6,7,12$ and 53 days. Mean and median hospital LOS was 10.8 (SD 16.7) and 6 days (range 1-140).

There was no association found between advanced age, underlying cardiac or lung disease, or immunosuppression with the need for ICU care or development of pneumonia. Need for ICU care was associated with greater mortality, with deaths in $3 / 13$ (23\%) of patients requiring ICU care compared to $2 / 73(3 \%)$ not requiring ICU $(p=0.01)$. Need for invasive MV was also associated with mortality, with deaths in 3/8 (40\%) of patients requiring invasive $\mathrm{MV}$ compared to $2 / 78(3 \%)$ of other patients $(\mathrm{p}=0.01)$. None of advanced age, underlying cardiac or lung disease, immunosuppression, pneumonia, or identification of a bacterial co-pathogen were associated with mortality.

\section{Discussion}

This study contributes to the growing body of evidence documenting that RSV is a serious pathogen in adults. In our cohort, adult hospitalization associated with RSV infection was not uncommon, and it was associated with a substantial rate of complications and mortality. Although the majority of adults were older, more than one-third were less than 65 years of age.

To complement the findings of this study, we conducted a literature search using MEDLINE (1946- December 2013), EMBASE (1947- December 2013), and PubMed (through December 31, 2013) databases. The references for each publication were reviewed to search for additional studies. After excluding studies with nosocomial cases, those focused specifically on ICU patients, or those that did not specifically describe RSV infections, we identified six previous cohort studies of RSV hospitalization in adults (Table 3) $[9,20,21,25,28,30]$. One of these cohorts had data in more than one publication $[9,31]$.

Despite substantial differences in time, geography, and means of diagnosis of RSV infections, the combined results provide a consistent and cohesive view of the characteristics of these patients and their disease (Tables 3 and 4). The majority of patients in these studies were older, and both underlying pulmonary and cardiac disease were common. There were however, differences in the distribution of underlying conditions. For instance, the proportion of immunosuppressed patients was noticeably greater in our study and in that of Widmer et al. than that of Lee et al $[21,25]$. This difference may be due to differences in patient populations cared for in study hospitals, definitions of immunosuppression, or criteria for RSV testing. In our study subjects were considered immunosuppressed if they had a hematologic malignancy, solid tumor on chemotherapy, chronic renal failure, liver cirrhosis, or if they were on immunosuppressive therapy (see Table 1). Lee et al. do not describe the conditions considered immunocompromising, and Widmer et al. appear to have 
Table 3 Published studies of adult patients hospitalized with acute respiratory symptoms and RSV infection

\begin{tabular}{|c|c|c|c|c|c|}
\hline Reference & Years of study & Type of study & Geographic location & Population & Means of diagnosis \\
\hline Lee [25] & $2009-2011$ & Retrospective cohort & Hong Kong, China & $\begin{array}{l}607 \text { adults ( } \geq 18 \text { years) with acute } \\
\text { respiratory infection }\end{array}$ & $\begin{array}{l}\text { Immunofluorescence assay, } \\
\text { nasopharyngeal aspirates }\end{array}$ \\
\hline Widmer [21] & 2006-2009 & Prospective cohort & Tennessee, USA & $\begin{array}{l}31 \text { adults } \geq 50 \text { years with respiratory } \\
\text { symptoms or non-localizing fever }\end{array}$ & $\begin{array}{l}\text { RT-PCR, frozen nasal and } \\
\text { throat swabs }\end{array}$ \\
\hline Falsey [9] & 1999-2003 & Prospective cohort & New York, USA & $\begin{array}{l}132 \text { adults } \geq 65 \text { years with } \\
\text { underlying cardiopulmonary disease } \\
\text { and acute respiratory symptoms }\end{array}$ & $\begin{array}{l}\text { Culture and RT-PCR of } \\
\text { nasopharyngeal specimens; and } \\
\text { acute and convalescent serology }\end{array}$ \\
\hline Dowell [28] & 1990-1992 & Prospective cohort & Ohio, USA & $\begin{array}{l}47 \text { community dwelling adults } \\
(\geq 18 \text { years) with pneumonia }\end{array}$ & Acute and convalescent serology \\
\hline Falsey [20] & 1989-1992 & Prospective cohort & New York, USA & $\begin{array}{l}145 \text { community dwelling adults } \\
\geq 65 \text { years with acute cardiopulmonary } \\
\text { conditions or influenza-like illness }\end{array}$ & $\begin{array}{l}\text { Antigen detection, culture on } \\
\text { nasopharyngeal specimens; acute } \\
\text { and convalescent serology }\end{array}$ \\
\hline Vikerfors [30] & 1971-1980 & Retrospective cohort & Orebro, Sweden & $\begin{array}{l}57 \text { adults (> } 16 \text { years) } \\
\text { with pneumonia }\end{array}$ & $\begin{array}{l}\text { Immunofluorescence assay on } \\
\text { nasopharyngeal secretions; acute } \\
\text { and convalescent serology }\end{array}$ \\
\hline
\end{tabular}

Abbreviations: RT-PCR, reverse transcriptase PCR; USA, United States of America.

included all malignancies, as well as splenectomy and HIV/AIDS [21,25].

Adult patients with RSV infection often experience symptoms of nasal congestion, productive cough, and low-grade fever that may or may not be followed within a few days by dyspnea and wheezing. Rates of runny nose or nasal congestion (22\% versus mean of $58 \%$ ) and wheezing (38\% versus mean of $64 \%$ ) were lower in our study compared to other studies $[4,9,20,21,25,28]$. This may be a limitation of our retrospective study design as treating clinicians may have failed to document these symptoms. Rates of other symptoms were similar to those observed in previous studies in which they could not facilitate differentiation from other respiratory illnesses.

Adult patients with RSV infection often present with an exacerbation of underlying cardiac or pulmonary disease,

Table 4 Characteristics and outcomes of adult patients hospitalized with acute respiratory symptoms and diagnosed with RSV as reported in published studies

\begin{tabular}{|c|c|c|c|c|c|c|c|}
\hline Study & $\begin{array}{l}\text { This study } \\
\text { (all adults) }\end{array}$ & $\begin{array}{l}\text { Lee } 2013 \\
\text { (all adults) }\end{array}$ & $\begin{array}{l}\text { Widmer, } 2012 \\
(50+\text { yrs })\end{array}$ & $\begin{array}{l}\text { Falsey, } 2005 \\
(65+y r s)\end{array}$ & $\begin{array}{l}\text { Dowell, } 1996 \\
\text { (all adults) }\end{array}$ & $\begin{array}{l}\text { Falsey, } 1995 \\
(65+\text { yrs })\end{array}$ & $\begin{array}{l}\text { Vikerfors, } 1987 \\
\text { (all adults) }\end{array}$ \\
\hline Age & $\begin{array}{l}\text { Median } 74 \text { yrs } \\
\text { IQR 62-85 }\end{array}$ & $\begin{array}{l}\text { Median } 80 \text { yrs } \\
\text { IQR 68-86 }\end{array}$ & $\begin{array}{l}\text { Median } 68 \text { yrs } \\
\text { IQR 56-78 }\end{array}$ & $\begin{array}{l}\text { Mean } 76 \text { yrs } \\
\text { SD } 13\end{array}$ & $\begin{array}{l}\text { Mean } 61 \text { yrs } \\
\text { range 21-89 }\end{array}$ & $\begin{array}{l}\text { Mean } 80 \text { yrs } \\
\text { SD } 8\end{array}$ & Median 75 yrs \\
\hline \multicolumn{8}{|l|}{ Underlying illness } \\
\hline Any & $97 \%$ & $87 \%$ & - & - & - & - & $56 \%$ \\
\hline Lung disease & $36 \%$ & $36 \%$ & $68 \%$ & $54 \%$ & $>65 \% *$ & $43 \%$ & $14 \%$ \\
\hline Cardiac disease & $52 \%$ & - & $48 \%$ & $58 \%$ & $>49 \% *$ & $63 \%$ & - \\
\hline Immunosuppressed & $31 \%$ & $14 \%$ & $61 \%$ & & - & - & - \\
\hline \multicolumn{8}{|l|}{ Complications } \\
\hline LRT complication & $52 \%$ & $72 \%$ & - & - & - & $63 \% \neq$ & - \\
\hline Pneumoniat & $30 \%$ & $42 \%$ & - & $31 \%$ & $40 \%$ & $48 \%$ & - \\
\hline Cardiovascular & $22 \%$ & $14 \%$ & - & $13 \%(\mathrm{CHF})$ & - & $20 \%(C H F) \neq$ & - \\
\hline \multirow[t]{2}{*}{ Co-pathogen identified } & $13 \%$ & $13 \%$ & 0 & $15 \%$ sputum & $14 \%$ & $17 \%$ sputum & $25 \%$ \\
\hline & & & & $3 \%$ blood & & $4 \%$ blood & \\
\hline \multicolumn{8}{|l|}{ Hospital course } \\
\hline Required ICU & $15 \%$ & - & $10 \%$ & $15 \%$ & $21 \%$ & $18 \%$ & - \\
\hline Required MV & $9 \%$ & $2 \%$ & $3 \%$ & $13 \%$ & $7 \%$ & $10 \%$ & - \\
\hline Length of stay & Median 6d & Median 7d & Median 3d & Mean 14d & Mean 9d & Mean 16d & - \\
\hline Case fatality rate & 6\% (in hospital) & $9 \%(30 d)$ & 7\% (in hospital) & 8\% (not specified) & - & 10\% (in hospital) & 0 \\
\hline
\end{tabular}

*65\% of patients had COPD, $44 \%$ had asthma; $49 \%$ had coronary artery disease; $37 \%$ congestive heart failure.

tConfirmed by CXR, or pulmonary infiltrates present on CXR.

‡Derived from principal discharge diagnoses.

Abbreviations: $\mathrm{LRT}=$ lower respiratory tract, $\mathrm{ICU}=$ intensive care unit, $\mathrm{MV}=$ mechanical ventilation. 
such as asthma, COPD, or CHF [32-34]. In our study, the admitting diagnosis for 23 (27\%) patients was recorded as an exacerbation of underlying lung disease or cardiac disease.

Lower respiratory tract complications including pneumonia were common in our study and in previous studies. Radiographic appearance of pneumonia associated with RSV infection has been noted to be variable, ranging from the absence of detected abnormality to small and unilateral pulmonary infiltrates, symmetrical or asymmetrical bilateral pulmonary infiltrates, or lobar consolidation $[7,20,31]$. This variability was also seen in our study.

In our cohort potential co-pathogens were identified in $13 \%$ of cases, similar to the rate observed in other published studies [9,25,28]. Vikerfors et al. observed much higher rates of co-pathogens, but their positive cultures for co-pathogens included results from nasopharyngeal samples rather than sputum or blood cultures as collected in other studies $[20,25,30,32]$. Widmer et al. report no coinfections in their cohort, although it is unclear whether pathogens present in non-sterile site specimens would have met criteria for co-infections in their patients [21].

Requirement for invasive mechanical ventilation, ICU care, mortality rates, and hospital lengths of stay were substantial and consistent across studies $[9,20,21,25,28,30]$. Vikerfors et al. observed a lower case fatality rate, which may be a result of the lower prevalence of underlying illness in their cohort [30].

Antibiotics were commonly prescribed in our cohort, as was the case in two other large studies of adult patients hospitalized with RSV $[20,25]$. While co-infections have been noted to occur, these numbers highlight the challenges of optimal use of antibiotics when viral respiratory infections have been diagnosed, but bacterial pathogens not identified. Due to difficulties with diagnosis of co-existent bacterial infections, the most effective way to reduce this overuse may be through prevention of RSV infection via enhanced infection control measures, development of effective prophylaxis or, as noted in a recent commentary, vaccination [35].

Advantages of our study are that we have included adults of all ages, and that testing was performed by RT-PCR. Previous testing for RSV has been done using antigen immunoassays or culture, which lack sensitivity, or using acute and convalescent serology, which cannot identify fatal cases, and may also lack sensitivity in immunocompromised patients or the frail elderly [11,36-38]. Most previously published studies using RT-PCR have also included only older adults $[9,21,25]$. Our study demonstrates that a substantial fraction of adult patients with RSV infection are not elderly; however, virtually all did have chronic underlying illnesses.

This study has several limitations. It took place in only one geographic location during only one season, and may therefore not be generalizable to other seasons or locations. Testing of patients was not systematic in all hospitals, and we may have failed to identify some infected patients. Our use of RT-PCR for diagnosis may have resulted in some false positive tests, although the Simplexa Flu A/B \& RSV assay (Focus Diagnostics, Cypress, CA) used for diagnosis has good performance characteristics and high specificity [39,40]. Finally, RSV infection may have been incidental and the requirement for hospital admission due to other causes; this may be a particular issue in immunocompromised patients, who may shed RSV for prolonged periods of time [18].

\section{Conclusion}

In conclusion, RSV infection in hospitalized adults is associated with substantial morbidity and the need for extended hospital stay, ICU care and mortality in adults of all ages with chronic underlying conditions. The data produced from this study are useful in supporting existing data from other areas, and reinforce that RSV infection in hospitalized adults is a global issue. There is need for ongoing research and development of effective RSV prophylaxis, vaccines and treatments.

\section{Competing interests}

The authors declare that they have no competing interests.

\section{Authors' contributions}

$\mathrm{CV}$, TM and AM conceived of the study, CV, KH, TM, KG, AA-D, and JN contributed to study design, $\mathrm{CV}, \mathrm{KH}, \mathrm{PH}, \mathrm{RM}$ and $\mathrm{AM}$ were responsible for the analysis and interpretation of the data. CV drafted the manuscript; all authors critically reviewed the manuscript for intellectual content and read and approved the final manuscript.

\section{Acknowledgements}

There was no external funding for this study.

\section{Author details}

${ }^{1}$ Department of Microbiology, Mount Sinai Hospital, Room 210, 600

University Avenue, M5G 1X5 Toronto, ON, Canada. ²Department of Medicine, University of Toronto, Toronto, Canada. ${ }^{3}$ Department of Laboratory Medicine and Pathobiology, University of Toronto, Toronto, Canada.

Received: 5 August 2014 Accepted: 24 November 2014 Published online: 13 December 2014

\section{References}

1. Ogra PL: Respiratory syncytial virus: the virus, the disease and the immune response. Paediatr Respir Rev 2004, 5(Suppl A):S119-S126.

2. Simoes EA: Respiratory syncytial virus infection. Lancet 1999, 354(9181):847-852.

3. Zambon MC, Stockton JD, Clewley JP, Fleming DM: Contribution of influenza and respiratory syncytial virus to community cases of influenza-like illness: an observational study. Lancet 2001, 358(9291):1410-1416.

4. Hall CB, Long CE, Schnabel KC: Respiratory syncytial virus infections in previously healthy working adults. Clin Infect Dis 2001, 33(6):792-796.

5. Henderson FW, Collier AM, Clyde WA Jr, Denny FW: Respiratory-syncytialvirus infections, reinfections and immunity. A prospective, longitudinal study in young children. N Engl J Med 1979, 300(10):530-534.

6. Glezen WP, Taber LH, Frank AL, Kasel JA: Risk of primary infection and reinfection with respiratory syncytial virus. Am J Dis Child 1986, 140(6):543-546. 
7. Hall CB: Respiratory syncytial virus and parainfluenza virus. N Engl J Med 2001, 344(25):1917-1928

8. Chanock RM, Kim HW, Vargosko AJ, Deleva A, Johnson KM, Cumming C, Parrott $\mathrm{RH}$ : Respiratory syncytial virus. I. Virus recovery and other observations during 1960 outbreak of bronchiolitis, pneumonia, and minor respiratory diseases in children. JAMA 1961, 176:647-653.

9. Falsey AR, Hennessey PA, Formica MA, Cox C, Walsh EE: Respiratory syncytial virus infection in elderly and high-risk adults. N Engl J Med 2005, 352(17):1749-1759.

10. Paes BA, Mitchell I, Banerji A, Lanctot KL, Langley JM: A decade of respiratory syncytial virus epidemiology and prophylaxis: translating evidence into everyday clinical practice. Can Respir J 2011, 18(2):e10-e19.

11. Falsey AR, Formica MA, Walsh EE: Diagnosis of respiratory syncytial virus infection: comparison of reverse transcription-PCR to viral culture and serology in adults with respiratory illness. J Clin Microbiol 2002, 40(3):817-820.

12. Walsh EE, Falsey AR, Hennessey PA: Respiratory syncytial and other virus infections in persons with chronic cardiopulmonary disease. Am J Respir Crit Care Med 1999, 160(3):791-795

13. Mehta J, Walsh EE, Mahadevia PJ, Falsey AR: Risk factors for respiratory syncytial virus illness among patients with chronic obstructive pulmonary disease. COPD 2013, 10(3):293-299.

14. Wendt $\mathrm{CH}$, Hertz Ml: Respiratory syncytial virus and parainfluenza virus infections in the immunocompromised host. Semin Respir Infect 1995, 10(4):224-231

15. Whimbey E, Couch RB, Englund JA, Andreeff M, Goodrich JM, Raad II, Lewis V, Mirza N, Luna MA, Baxter B, Tarrand JJ, Bodey GP: Respiratory syncytial virus pneumonia in hospitalized adult patients with leukemia. Clin Infect Dis 1995, 21(2):376-379.

16. Chemaly RF, Ghosh S, Bodey GP, Rohatgi N, Safdar A, Keating MJ, Champlin RE, Aguilera EA, Tarrand JJ, Raad II: Respiratory viral infections in adults with hematologic malignancies and human stem cell transplantation recipients: a retrospective study at a major cancer center. Medicine (Baltimore) 2006, 85(5):278-287.

17. Martino R, Porras RP, Rabella N, Williams JV, Ramila E, Margall N, Labeaga R, Crowe JE Jr, Coll P, Sierra J: Prospective study of the incidence, clinical features, and outcome of symptomatic upper and lower respiratory tract infections by respiratory viruses in adult recipients of hematopoietic stem cell transplants for hematologic malignancies. Biol Blood Marrow Transplant 2005, 11(10):781-796.

18. Couch RB, Englund JA, Whimbey E: Respiratory viral infections in immunocompetent and immunocompromised persons. Am J Med 1997 102(3 A):2-9.

19. Englund JA, Sullivan CJ, Jordan MC, Dehner LP, Vercellotti GM, Balfour HH Jr: Respiratory syncytial virus infection in immunocompromised adults. Ann Intern Med 1988, 109(3):203-208.

20. Falsey AR, Cunningham CK, Barker WH, Kouides RW, Yuen JB, Menegus M, Weiner LB, Bonville CA, Betts RF: Respiratory syncytial virus and influenza A infections in the hospitalized elderly. J Infect Dis 1995, 172(2):389-394.

21. Widmer K, Zhu Y, Williams JV, Griffin MR, Edwards KM, Talbot HK: Rates of hospitalizations for respiratory syncytial virus, human metapneumovirus, and influenza virus in older adults. J Infect Dis 2012, 206(1):56-62.

22. Thompson WW, Shay DK, Weintraub E, Brammer L, Cox N, Anderson L, Fukuda K: Mortality associated with influenza and respiratory syncytial virus in the United States. JAMA 2003, 289(2):179-186.

23. Han LL, Alexander JP, Anderson LJ: Respiratory syncytial virus pneumonia among the elderly: An assessment of disease burden. J Infect Dis 1999 179(1):25-30.

24. Zhou H, Thompson WW, Viboud CG, Ringholz CM, Cheng PY, Steiner C, Abedi GR, Anderson LJ, Brammer L, Shay DK: Hospitalizations associated with influenza and respiratory syncytial virus in the United States, 1993-2008. Clin Infect Dis 2012, 54(10):1427-1436.

25. Lee N, Lui GC, Wong KT, Li TC, Tse EC, Chan JY, Yu J, Wong SS, Choi KW, Wong RY, Ngai KL, Hui DS, Chan PK: High Morbidity and Mortality in Adults Hospitalized for Respiratory Syncytial Virus Infections. Clin Infect Dis 2013, 57(8):1069-1077.

26. O'Shea MK, Ryan MA, Hawksworth AW, Alsip BJ, Gray GC: Symptomatic respiratory syncytial virus infection in previously healthy young adults living in a crowded military environment. Clin Infect Dis 2005, 41(3):311-317.

27. O'Shea MK, Pipkin C, Cane PA, Gray GC: Respiratory syncytial virus: an important cause of acute respiratory illness among young adults undergoing military training. Influenza Other Respir Viruses 2007, 1(5-6):193-197.

28. Dowell SF, Anderson LJ, Gary HE Jr, Erdman DD, Piouffe JF, File TM Jr, Marston BJ, Breiman RF: Respiratory syncytial virus is an important cause of community-acquired lower respiratory infection among hospitalized adults. J Infect Dis 1996, 174(3):456-462.

29. Hall WJ, Hall CB, Speers DM: Respiratory syncytial virus infection in adults: clinical, virologic, and serial pulmonary function studies. Ann Intern Med 1978, 88(2):203-205

30. Vikerfors T, Grandien M, Olcen P: Respiratory syncytial virus infections in adults. Am Rev of Respir Dis 1987, 136(3):561-564.

31. Walsh EE, Peterson DR, Falsey AR: Is clinical recognition of respiratory syncytial virus infection in hospitalized elderly and high-risk adults possible? J Infect Dis 2007, 195(7):1046-1051

32. Falsey $A R$, Walsh EE: Respiratory syncytial virus infection in elderly adults. Drugs Aging 2005, 22(7):577-587.

33. De Serres G, Lampron N, La Forge J, Rouleau I, Bourbeau J, Weiss K, Barret B, Boivin G: Importance of viral and bacterial infections in chronic obstructive pulmonary disease exacerbations. J Clin Virol 2009, 46(2):129-133.

34. Dimopoulos G, Lerikou M, Tsiodras S, Chranioti A, Perros E, Anagnostopoulou U, Armaganidis A, Karakitsos P: Viral epidemiology of acute exacerbations of chronic obstructive pulmonary disease. Pulm Pharmacol Ther 2012, 25(1):12-18.

35. Falsey AR: Editorial commentary: respiratory syncytial virus: a global pathogen in an aging world. Clin Infect Dis 2013, 57(8):1078-1080.

36. Falsey AR, McCann RM, Hall WJ, Criddle MM: Evaluation of four methods for the diagnosis of respiratory syncytial virus infection in older adults. J Am Geriatr Soc 1996, 44(1):71-73.

37. Khanna N, Widmer AF, Decker M, Steffen I, Halter J, Heim D, Weisser M, Gratwohl A, Fluckiger $\mathrm{U}$, Hirsch HH: Respiratory syncytial virus infection in patients with hematological diseases: single-center study and review of the literature. Clin Infect Dis 2008, 46(3):402-412

38. Caram LB, Chen J, Taggart EW, Hillyard DR, She R, Polage CR, Twerksy J, Schmader K, Petti CA, Woods CW: Respiratory syncytial virus outbreak in a long-term care facility detected using reverse transcriptase polymerase chain reaction: an argument for real-time detection methods. J Am Geriatr Soc 2009, 57(3):482-485.

39. Hindiyeh $M$, Kolet $L$, Meningher $T$, Weil M, Mendelson $E$, Mandelboim M: Evaluation of Simplexa Flu A/B \& RSV for direct detection of influenza viruses (A and $B$ ) and respiratory syncytial virus in patient clinical samples. J Clin Microbiol 2013, 51(7):2421-2424.

40. Woodberry MW, Shankar R, Cent A, Jerome KR, Kuypers J: Comparison of the Simplexa FluA/B \& RSV direct assay and laboratory-developed real-time PCR assays for detection of respiratory virus. J Clin Microbiol 2013, 51(11):3883-3885.

\section{doi:10.1186/s12879-014-0665-2}

Cite this article as: Volling et al:: Respiratory syncytial virus infectionassociated hospitalization in adults: a retrospective cohort study. BMC Infectious Diseases 2014 14:665.

\section{Submit your next manuscript to BioMed Central and take full advantage of:}

- Convenient online submission

- Thorough peer review

- No space constraints or color figure charges

- Immediate publication on acceptance

- Inclusion in PubMed, CAS, Scopus and Google Scholar

- Research which is freely available for redistribution 